\title{
Effect of thyme oil vapours exposure on phenylalanine ammonia-lyase (PAL) and lipoxygenase (LOX) genes expression, and control of anthracnose in 'Hass' and 'Ryan' avocado fruit
}

Malick Bill $^{\mathrm{a}}$, Lise Korsten ${ }^{\mathrm{b}}$, Fabienne Remize $^{\mathrm{c}}$, Marcin Glowacz ${ }^{\mathrm{a}}$, Dharini Sivakumar ${ }^{\mathrm{a},{ }^{*}}$

${ }^{\text {a} P h y t o c h e m i c a l ~ F o o d ~ N e t w o r k ~ R e s e a r c h ~ g r o u p, ~ D e p a r t m e n t ~ o f ~ C r o p ~ S c i e n c e s, ~ T s h w a n e ~ U n i v e r s i t y ~ o f ~ T e c h n o l o g y, ~}$ Private Bag X680, Pretoria West 0001, South Africa

${ }^{\mathrm{b}}$ Department of Plant Science, University of Pretoria, University of Pretoria Private bag X20 Hatfield 0028

${ }^{c}$ Université de La Réunion, ESIROI-UMR QualiSud, Parc Technologique Universitaire, 2 Rue Joseph, Wetzell 97490, Sainte Clotilde, Réunion Island

*Corresponding author:

D. Sivakumar (SivakumarD@ @ut.ac.za or dharinisivakumar@yahoo.co.uk);

Tel: +27 12382 5303; Fax: +27 123825869

\section{Highlights}

- Thyme oil exposure led to up-regulation of PAL gene expression in Hass and Ryan fruit.

- Thyme oil exposure led to down-regulation of LOX gene expression in both cultivars.

- Higher level of epicatechin was associated with lower anthracnose incidence.

- Thyme oil vapours act as elicitors of plant defence against $C$. gloeosporioides.. 


\section{ABSTRACT}

The effect of thyme oil $\left(96 \mu \mathrm{L} \mathrm{L}^{-1}\right)$ vapours on the expression of phenylalanine ammonia-lyase (PAL) and lipoxygenase (LOX) genes, and control of anthracnose was investigated in naturally infected 'Hass' and 'Ryan' avocado fruit stored for $21 \mathrm{~d}$ at $7-7.5^{\circ} \mathrm{C}$, and thereafter kept for $5 \mathrm{~d}$ at $20{ }^{\circ} \mathrm{C}$, simulating the supply chain conditions. Exposure to thyme oil vapours prior to cold storage resulted in up-regulation of the PAL gene expression in both 'Hass' and 'Ryan' avocado when compared with untreated fruit and those treated with prochloraz ${ }^{\circledR}$. The higher expression of PAL genes was observed in 'Ryan'. Thyme oil vapours exposure resulted in the higher epicatechin content. At the same time, exposure to thyme oil vapours led to down-regulation of LOX genes expression in both cultivars. Thus, simultaneous up-regulation of PAL genes and down-regulation of LOX genes in avocados exposed to thyme oil vapours prior to cold storage was associated with higher epicatechin content in the fruit skin and enhanced anthracnose disease resistance. Therefore, it can be concluded that postharvest application of thyme oil vapours increases anthracnose disease resistance in avocado fruit 'Hass' and 'Ryan'.

Keywords:

Persea americana,

Colletotrichum gloeosporioides,

Postharvest decay

Epicatechin

Essential oils 


\section{Introduction}

The avocado fruit (Persea americana Mill.) is popular mostly due to being nutritious (Dreher and Davenport, 2013), and its excellent rich, nutty and buttery flavour. Avocado also contains numerous phenolic acids and flavonoids. Furthermore, avocado contains high level of fatty acids, in particular oleic acid, (Ferreyra et al., 2016; Lu et al., 2009, Pedreschi et al., 2016), and very little sugar content compared to other fruit (USDA, 2011). Avocados are also rich in vitamin E and phytosterols (Dreher and Davenport, 2013).

Anthracnose, caused by Colletotrichum gloeosporioides Penz., is the main postharvest disease responsible for severe losses throughout the supply chain (Bill et al., 2014a). The pathogen remains quiescent and does not develop until the fruit begins to ripen (Prusky et al., 2013; Prusky and Litcher, 2007). It has been reported that antifungal diene compound (AFD; 1acetoxy-2-hydroxy-4-oxo-heneicosa-12, 15-diene) primarily involved in the resistance of unripe fruit to fungal attack (Prusky et al., 1983; Prusky et al., 1982) declines as fruit ripens, due to oxidative metabolism by the lipoxygenase enzyme. This consequently facilitates a rapid growth of the pathogen through the peel and into the fruit pulp (Prusky et al., 2013; Prusky et al., 1991). The evolution of ethylene speeds up the infection process making the fruit unmarketable. The activity of lipoxygenase is known to be modulated by the level of its inhibitor - epicatechin (Karni et al., 1989; Prusky, 1996; Prusky et al., 2013), a product of the phenylpropanoid pathway. (Table 1) 
Table 1. Primers selected for the gene expression analyses of avocado fruits.

\begin{tabular}{|c|c|c|c|c|c|}
\hline Gene & $\begin{array}{c}\text { NCBI } \\
\text { accessionnumber }\end{array}$ & $\begin{array}{l}\text { Primer sequence } \\
\text { (forward/reverse) }\end{array}$ & $\begin{array}{l}\text { Amplicon } \\
\text { size }\end{array}$ & $\begin{array}{c}\text { PCR } \\
\text { efficiency }(\%)^{\mathrm{a}}\end{array}$ & $\begin{array}{c}\mathbf{R}^{2} \text { of } \\
\text { standardcurve }^{\mathbf{a}}\end{array}$ \\
\hline $\operatorname{Actin}^{b}$ & GU272027.1 & $\begin{array}{l}\text { AGGCGTTATGGTTGGGATGG/ } \\
\text { GTTCTTCAGGAGCCACACGG }\end{array}$ & 161 & 88 & 0.927 \\
\hline PAL & U16130.1 & $\begin{array}{l}\text { AGGTCAGGGTGGAGTTGTCT/ } \\
\text { GGCTCCTCCTTGCTTGGTTC }\end{array}$ & 152 & 125 & 0.915 \\
\hline LOX & AD001673 & $\begin{array}{l}\text { CCCAGCTCCAGACCCTTCTT/ } \\
\text { ACTGGTCGTCGTCGTTCATC }\end{array}$ & 195 & 87 & 0.981 \\
\hline
\end{tabular}

A postharvest application of synthetic non-systemic fungicide prochloraz ${ }^{\circledR}$ is currently being used to control anthracnose. However, increasing consumer concerns regarding the food safety, has brought a need for alternative methods to control postharvest decay. There is a growing interest in the research focused on activating natural compounds that can act as resistance inducers or elicitors for sustainable plant protection against pathogens, and thus prolonging storability of the fruit (Glowacz and Rees, 2016; Sivakumar and Bautista-Banos, 2014). One of the emerging options is the use of essential oils due to their antifungal, ecofriendly and biodegradable properties (Calo et al., 2015; Prakash et al., 2015; Sivakumar and Bautista-Banos, 2014). Laird and Phillips (2011) have stated that because of their high volatility, essential oils applied in the vapour phase can be effective even at low concentrations, which makes them feasible as fumigants in the postharvest systems.

Thyme oil vapours applied under modified atmosphere packaging (MAP) conditions, have been reported to effectively control the anthracnose disease in 'Hass' avocado (Sellamuthu 
et al., 2013a), with thymol - a natural monoterpene phenol derivative - being the active ingredient (Bill et al., 2014b; Sellamuthu et al., 2013b). Thyme oil has been classified as a minimum risk pesticide and is currently exempted from the pesticide residues tolerance requirements (EPA, 2015).

The exposure to thyme oil vapours has previously been reported to reduce anthracnose disease incidence by inducing the expression of pathogenesis-related (PR) genes, i.e. chitinase and 1-3 $\beta$-glucanase (Bill et al., 2016) in 'Hass' and 'Ryan' avocados. These enzymes are capable of hydrolysing polymers of fungal cell walls and are therefore implicated in the plant defence mechanisms (Mauch et al., 1988), reducing the fruit decay. However, other mechanisms may also be involved in increasing fruit resistance, and to the best of our knowledge, there is no information in the literature on the effect of thyme oil vapours exposure on the expression of PAL and LOX genes in the mesocarp of avocado fruit. Thus, the objective of this study was to investigate the effect of thyme oil vapours on their expression in 'Hass' (most exported cultivar in South Africa) and 'Ryan' (noted to be more resistant to anthracnose in our previous work) avocado fruit using real-time PCR.

\section{Materials and methods}

\subsection{Plant material and handling}

Freshly harvested, unblemished avocado fruit 'Hass' and 'Ryan' were obtained from Bassan Packers (Limpopo Province, South Africa) at commercial maturity. Fruit were washed in sodium hypochlorite $(0.01 \% \mathrm{NaOCl})$ solution for $5 \mathrm{~min}$ and were gently dried afterwards. Subsequently, avocado fruit were i) dipped for 5 min in $0.05 \%$ prochloraz $^{\circledR}$ - the commercial treatment; ii) dipped in distilled water for $5 \mathrm{~min}$ - untreated control; iii) exposed to thyme oil 
vapours for $24 \mathrm{~h}$ at $20^{\circ} \mathrm{C}$. The thyme oil vapour exposure was performed as previously described in Bill et al. (2016). Briefly, avocado fruit were placed in the $10 \mathrm{~L}$ containers, avoiding direct contact between the fruit and thyme oil $\left(96 \mu \mathrm{L} \mathrm{L}^{-1}\right)$. 'Hass' and 'Ryan' fruit were subsequently stored for $21 \mathrm{~d}$ at 7 and $7.5{ }^{\circ} \mathrm{C}$, respectively to simulate the shipping conditions, and thereafter held at $20{ }^{\circ} \mathrm{C}$, RH $70 \%$ for $5 \mathrm{~d}$ to simulate the retail shelf-life conditions. Each treatment had ten replicate boxes, each containing eighteen fruits, i.e. 180 fruit per treatment, equalling to 540 fruit per trial. The experiment was repeated twice.

\subsection{Anthracnose incidence and severity}

The incidence of anthracnose was recorded as a \% (out of a 100) of infected fruit (naturally infected) and lesion size was measured at the end of the retail shelf-life stage, i.e. after $21 \mathrm{~d}$ of cold storage plus $5 \mathrm{~d}$ at $20^{\circ} \mathrm{C}$. Naturally infected fruit were used in order evaluate the effect of TO fumigation on the natural inoculum load from the field under the current shipment conditions.

\subsection{PAL and LOX genes expression}

One fruit from each box $(1 \times 10 \times 5)$ was taken out at day 0 and after 7, 14, $21 \mathrm{~d}$, and finally after additional $5 \mathrm{~d}$ at $20{ }^{\circ} \mathrm{C}$. For genes expression analysis, fruit samples were cut into small pieces, frozen in liquid nitrogen and stored at $-80{ }^{\circ} \mathrm{C}$ until use. Samples were freeze-dried and ground into powder prior the analysis.

\subsubsection{RNA Extraction}

High quality total RNA was obtained from the fruit following the protocol of Landi and Romanazzi (2011). Briefly, $10 \mathrm{~g}$ of avocado pulp tissue was ground in liquid nitrogen, and 300 mg of the resulting powder was collected for RNA extraction. Total RNA was extracted using the total RNA plant mini kit (Zymo Research Corporation, Inqaba Biotech, South Africa). RNA 
integrity was verified by running samples on the agarose gels that were stained with SYBRSafe (Invitrogen, Carlsbad, CA, USA). Each RNA sample $(1 \mu \mathrm{g})$ was analysed by electrophoresis in $1.8 \%(\mathrm{w} / \mathrm{v})$ agarose and $1.0 \%(\mathrm{v} / \mathrm{v})$ formaldehyde denaturing gel according to Masek et al. (2005). The RNA purity was assessed based on the absorbance ratio of 1.80 to 1.90 at $260 / 280$ $\mathrm{nm}$ and 1.80 to 2.00 at 230/260 nm, using the BioPhotometer plus (Eppendorf Inc., Westbury, NY, USA).

\subsubsection{Reverse Transcription PCR}

A total of $1 \mu \mathrm{g}$ of RNA was used for cDNA synthesis with reverse-transcription PCR, using Transcriptor first strand cDNA synthesis kits (Roche Applied Science, Penzberg, Germany) according to the manufacturer's instructions. From each RNA extraction, cDNA synthesis was performed twice, and the products were mixed before the gene expression studies.

\subsubsection{Primers and Reference Gene Selection}

Specific primer sets were designed using the Primer3 software (http://biotools.umassmededu/bioapps/primer3_www.cgi) from the specific sequence of Persea americana deposited in NCBI GenBank. The primer pairs (Supplementary material) were chosen and validated in silico using primer BLAST specific analysis (http://www.ncbi.nlm.nih.gov/Blast.cgi) and then according to qPCR efficiency calculation, as described later. The relative expression stabilities of the candidate reference gene encoding actin were validated using the geNorm method, using the 3.5 version.20.

\subsubsection{Quantitative Real-Time PCR}

Gene expression analysis was performed by qPCR, using a SYBR-green dye system, according to Minimum Information for Publication of Quantitative qPCR Experiments (MIQE) guidelines (Bustin et al., 2009). The comparative $-\Delta \Delta \mathrm{C}_{\mathrm{t}}$ method (Livak and Schmittgen, 2001) 
was used to evaluate the relative quantities of each of the amplified products in the samples. The reference gene was actin and the reference sample was $0 \mathrm{~d}$. The qPCR reactions were performed in a MicroAmp ${ }^{\circledR}$ Fast Optical 96-Well Reaction Plate (Applied Biosystems, Carlsbad, CA, USA) using the Sybr ${ }^{\circledR}$ Green Master mix (Applied Biosystems, Warrington, UK) on a Step One Plus ${ }^{\mathrm{TM}}$ Real-Time PCR System (Applied Biosystems, Carlsbad, CA, USA) under the following conditions: an initial activation cycle $\left(10 \mathrm{~min}\right.$ at $\left.95^{\circ} \mathrm{C}\right)$, followed by 40 cycles of denaturation, annealing and polymerisation $\left(15 \mathrm{~s}\right.$ at $95{ }^{\circ} \mathrm{C}, 60 \mathrm{~s}$ at $\left.60{ }^{\circ} \mathrm{C}\right)$. PCR amplification was conducted in a total volume of $20 \mu \mathrm{L}$, with $1 \mu \mathrm{L}$ of diluted (1:20) cDNA (duplicates), $50 \mathrm{nmol} \mathrm{L}^{-1}$ primers and $10 \mu \mathrm{L}$ of $\operatorname{Sybr}^{\circledR}$ Green Master mix. To determine the specificity of the amplicons, melting curve analysis were performed over the temperature range of $60-95{ }^{\circ} \mathrm{C}$. The qPCR efficiency (E) of each primer pair was determined using standard curves generated according to the equation $\mathrm{E}=$ $10^{-1} /$ slope of five triplicate cDNA pool dilutions (undiluted, $0.25,0.0625,0.015$, and 0.003 ).

\subsection{Quantification of (-)-epicatechin content}

A set of three fruit from ten replicate boxes $(3 \times 10)$ per treatment were used for the quantification of (-)-epicatechin content. Avocado fruit samples were frozen in the liquid nitrogen and kept at $-80{ }^{\circ} \mathrm{C}$ until use. Samples were freeze-dried using a VirTis BenchTop Freeze Dryer (SP Scientific, New York, USA) and ground into powder prior to the analysis.

(-)-Epicatechin content in the fruit was measured according to the method of Zhang and Zuo (2004) with some modifications. Freeze-dried samples (5 g) were extracted with $40 \mathrm{~mL}$ of $70 \%(\mathrm{v} / \mathrm{v})$ methanol $(\mathrm{MeOH}) .100 \mu \mathrm{L}$ of naphthol (final concentration of $0.1 \mathrm{mg} \mathrm{L}^{-1}$ ) were added as an internal standard in order to improve the precision and accuracy of the results. The mixture was agitated and subsequently incubated for $2 \mathrm{~h}$ at $60{ }^{\circ} \mathrm{C}$. The samples were centrifuged and the resulting $500 \mu \mathrm{L}$ of supernatants were dried in a SpeedVac ${ }^{\mathrm{TM}}$ (Thermo Fisher Scientific, 
Massachusetts, USA). Dried samples were reconstituted with $150 \mu \mathrm{L}$ of acetonitrile, followed by $50 \mu \mathrm{L}$ BSTFA [N,O-Bis (trimethylsilyl) trifluoroacetamide) $]$ and $1 \%$ TMCS (trimethylchlorosilane). BSTFA and TMCS were used as silylation reagents. The mixture was agitated and then derivatised by incubating for $1 \mathrm{~h}$ at $80{ }^{\circ} \mathrm{C}$. After incubation, the mixture was agitated again and then transferred into GC vials. One $\mu \mathrm{L}$ was injected into a GC/MS (7890A Gas Chromatograph with 5975C Mass Spectrometer; Agilent Chemetrix (Pty) Ltd, Johannesburg, South Africa). The separation was performed on a DB-5ms Ultra Inert, $30 \mathrm{~m} \mathrm{x}$ $0.25 \mathrm{~mm}, 0.25 \mu \mathrm{m}$ column. The GC/MS conditions and run parameters were set according to Zhang and Zuo (2004). Helium was used as a carrier gas at flow rate of $1 \mathrm{~mL} \mathrm{~min}^{-1}$. Identification of (-)-epicatechin was achieved by matching the peaks retention time (RT) with authentic standards. The individual compounds were quantified by calculating their peak areas, and their content was expressed on dry weight (DW) basis.

\subsection{Physical properties of the fruit}

Flesh firmness was determined along the equator of the fruit using a Chatillon Penetrometer, Model DFM50 (Ametek, Largo, Florida, USA) with an $8 \mathrm{~mm}$ diameter flat-head stainless steel cylindrical probe - puncture test. Skin and flesh colour measurements were taken using a Minolta Chroma meter CR0-2000 (Minolta Camera Co. Ltd, Tokyo, Japan), calibrated with manufacturer's standard white plate.

\subsection{Statistical analysis}

A complete randomised design approach was adopted in this study. The experiments were repeated twice and the data were analysed with the General Linear Model (GLM) procedure in the SAS (Statistical Analysis System) computer program (SAS Enterprise Guide 
4.0; SAS Institute, 2006, Cary, NC). Mean values were separated by LSD values (5 \%) using the Least Significant Difference (LSD) test.
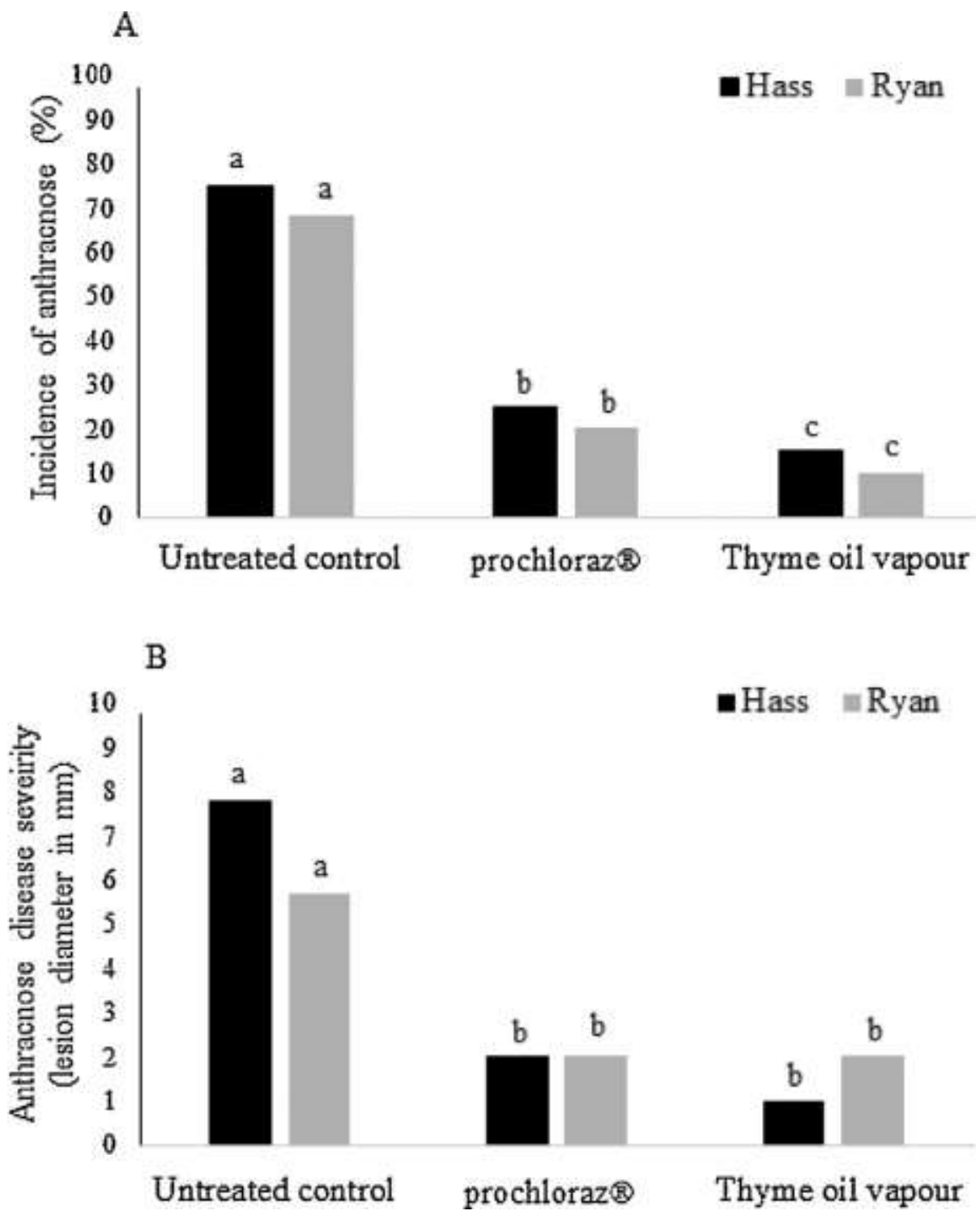

Fig. 1. Disease incidence (A) and severity (B) in naturally infected 'Hass' and 'Ryan' avocado fruit after $21 \mathrm{~d}$ of cold storage followed by $5 \mathrm{~d}$ shelf-life. Fruit were treated with thyme oil $\left(96 \mu \mathrm{L} \mathrm{L}^{-1}\right)$ vapours for $24 \mathrm{~h}$ at $20{ }^{\circ} \mathrm{C}$ or dipped for $5 \mathrm{~min}$ in $0.05 \%$ prochloraz ${ }^{\circledR}$ - the commercial treatment. Different letters indicate significant difference $(\mathrm{P}<0.05)$ determined using the LSD test. 


\section{Results and discussion}

\subsection{Effect of thyme oil vapours on anthracnose incidence}

The exposure of avocado fruit to thyme oil vapours prior to cold storage resulted in nearly $60 \%$ lower anthracnose disease incidence in both naturally infected 'Hass' and 'Ryan' avocados when compared with untreated control (Fig. 1A). Compared to the commercial treatment (prochloraz $^{\circledR}$ ), thyme oil vapours effectively reduced the incidence of anthracnose by $10 \%$ in 'Hass' and 'Ryan' avocados, while the lesion size was not affected (Fig. 1B). These results are in agreement with Sellamuthu et al. (2013a) and Bill et al. (2016). In addition, the current study showed that 'Ryan' seems to be more resistant to anthracnose than 'Hass'.

\subsection{Effect of thyme oil vapours on PAL and LOX genes expression and (-)-epicatechin content}

Gene expression analysis was quantified from naturally infected avocado fruit ('Hass' and 'Ryan') subjected to TO fumigation, commercial treatment (prochloraz ${ }^{\circledR}$ ) and untreated control in order to quantify the eliciting effect of the treatment alone. Even though the expression of PAL genes increased over the cold storage period in both 'Hass' and 'Ryan' avocados (Fig. $2 \mathrm{~A}$ and $\mathrm{B}$ ), it is worth noting that higher expression of the PAL genes was reported for both cultivars in the fruit exposed to thyme oil vapours prior to cold storage. The basal level of expression of PAL genes was higher in 'Ryan' than in 'Hass' avocados. In 'Hass' avocados, PAL gene expression was increased after $21 \mathrm{~d}$ of cold storage, with increased expression of 11.4fold in untreated fruit, which corresponded with 18.6-fold and 42.2-fold increase in fruit treated with prochloraz ${ }^{\circledR}$ and those exposed to thyme oil vapours, respectively. In 'Ryan', the expression of PAL gene was also increased after $21 \mathrm{~d}$ of cold storage, with increased expression of 96.8fold in untreated fruit, which corresponded with 101.4-fold and 174.5-fold increase in the fruit treated with prochloraz ${ }^{\circledR}$ and those exposed to thyme oil vapours, respectively. 
A

- Untreated control $\square$ Prochloraz dip $\square$ TO fumigation

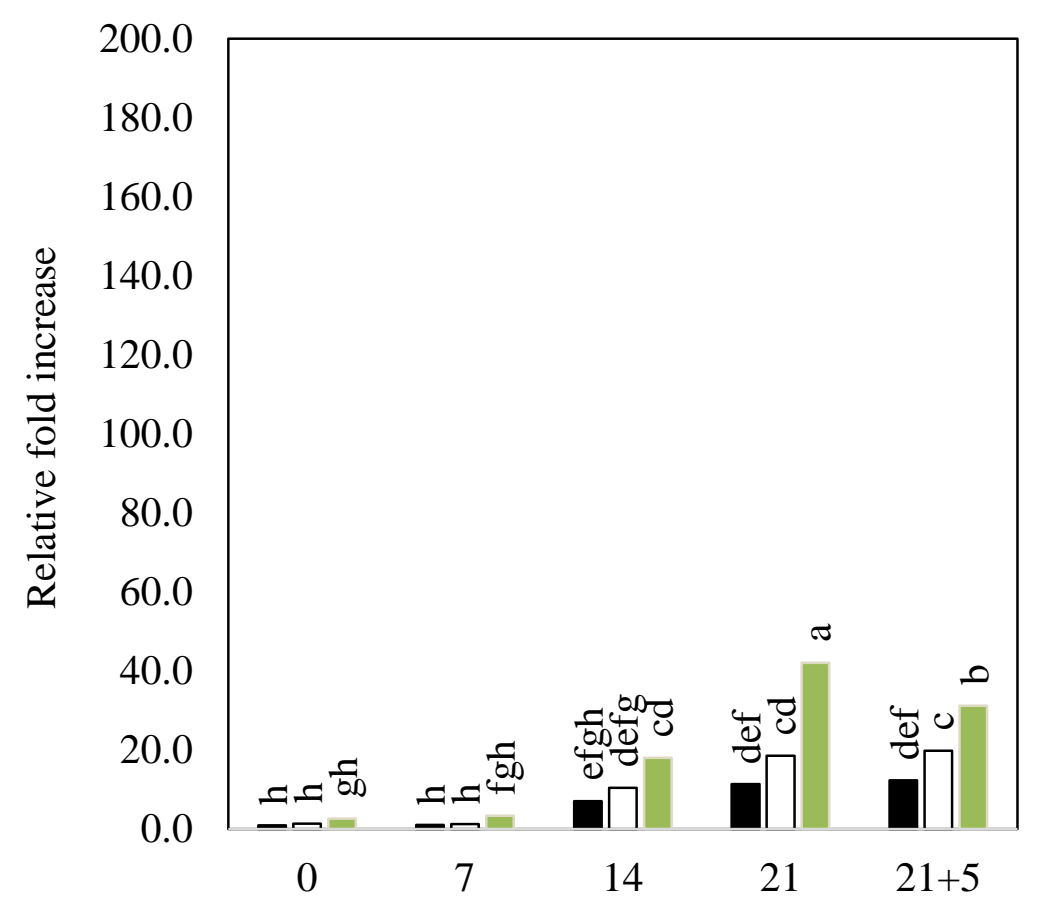

Days after treatment
B

- Untreated control $\square$ Prochloraz dip $\quad$ TO fumigation

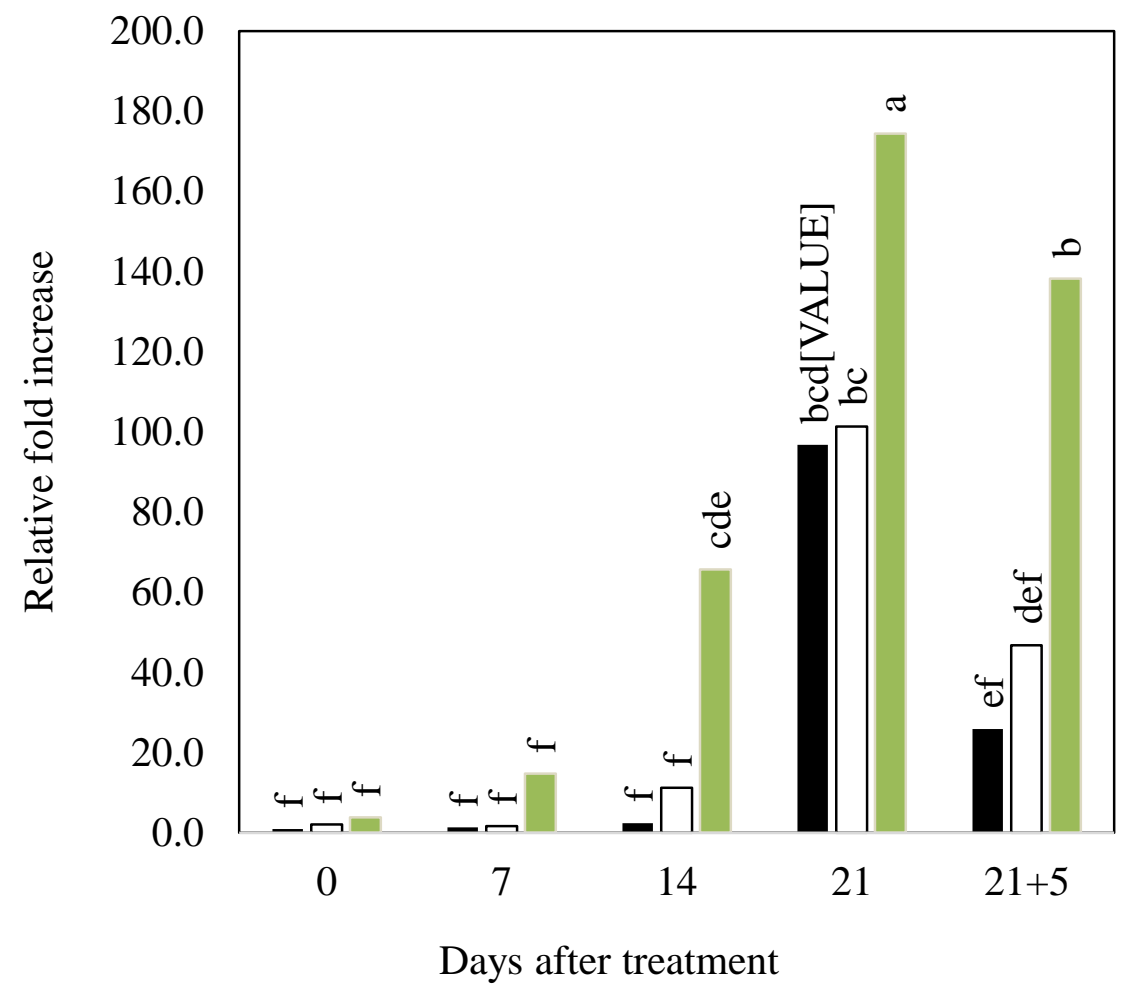

Fig. 2. Effect of thyme oil vapour exposure on PAL gene expression in 'Hass' (A) and 'Ryan' (B) avocado. Fruit were treated with thyme oil $\left(96 \mu \mathrm{L} \mathrm{L}^{-1}\right)$ vapours for $24 \mathrm{~h}$ at $20{ }^{\circ} \mathrm{C}$ or dipped for $5 \mathrm{~min}$ in $0.05 \%$ prochloraz ${ }^{\circledR}$ - the commercial treatment.. The transcript accumulation was determined by qPCR in fruit after the treatment, and subsequently after 7, 14, 21 and $21+5 \mathrm{~d}$. Different letters indicate significant difference $(P<0.05)$ determined using the LSD test. 
The expression of LOX genes increased over the cold storage period in both 'Hass' and 'Ryan' avocados in untreated fruit and those dipped in prochloraz ${ }^{\circledR}$ (Fig. 3A and B). However, this increase was limited in the fruit exposed to thyme oil vapours prior to cold storage, suggesting down-regulation of LOX genes expression in both cultivars. In 'Hass' avocados, LOX gene expression was increased after $21 \mathrm{~d}$ of cold storage, with increased expression of 15.1-fold in untreated fruit, which corresponded with 9.3-fold and 4.5-fold increase in fruit treated with prochloraz ${ }^{\circledR}$ and those exposed to thyme oil vapours, respectively. In 'Ryan' avocados, the expression of LOX gene was also increased after $21 \mathrm{~d}$ of cold storage, with increased expression of 13.2-fold in untreated fruit, which corresponded with 10.5-fold and 2.6fold increase in fruit treated with prochloraz ${ }^{\circledR}$ and those exposed to thyme oil vapours, respectively (Fig. 3A and B).

Exposure of both avocado cultivars to thyme oil vapours prior to cold storage led to a higher content of the flavan-3-ol, (-)-epicatechin in the fruit skin compared to both the prochloraz ${ }^{\circledR}$ dip and untreated control treatments (Fig. 4). In 'Hass' avocados (-)-epicatechin content was higher than in untreated fruit and those dipped in prochloraz ${ }^{\circledR}$, whereas in 'Ryan' avocados, their content was higher than in untreated fruit but not different from those dipped in prochloraz ${ }^{\circledR}$ (Fig. 4). 

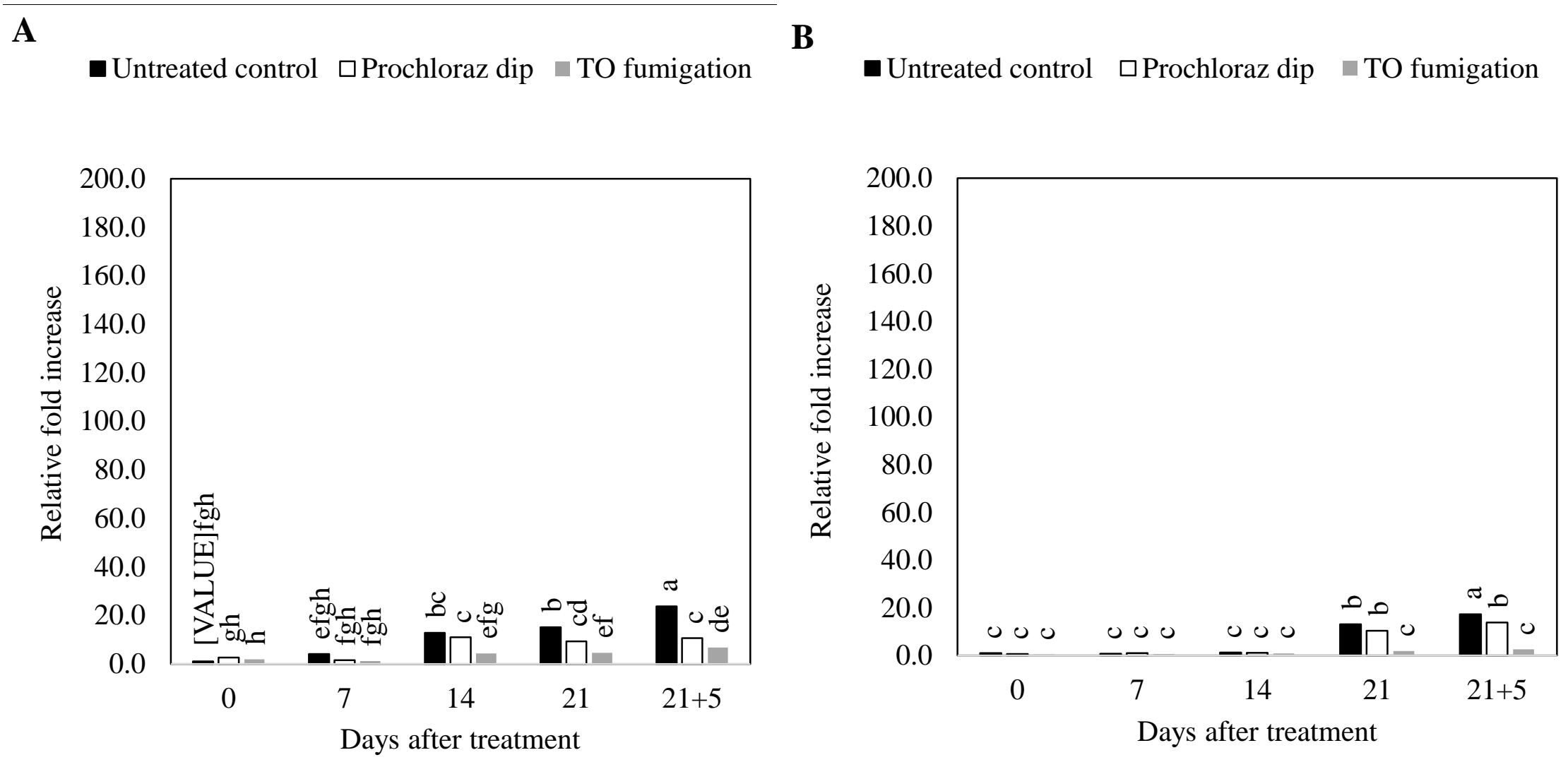

Fig. 3. Effect of thyme oil vapour exposure on LOX gene expression in 'Hass' (A) and 'Ryan' (B) avocado. Fruit were treated with thyme oil ( $96 \mu \mathrm{L} \mathrm{L}^{-1}$ ) vapours for $24 \mathrm{~h}$ at $20{ }^{\circ} \mathrm{C}$ or dipped for $5 \mathrm{~min}$ in $0.05 \%$ prochloraz ${ }^{\circledR}$ - the commercial treatment.. The transcript accumulation was determined by qPCR in fruit after the treatment, and subsequently after 7, 14, 21 and $21+5 \mathrm{~d}$. Different letters indicate significant difference $(\mathrm{P}<0.05)$ determined using the LSD test. 


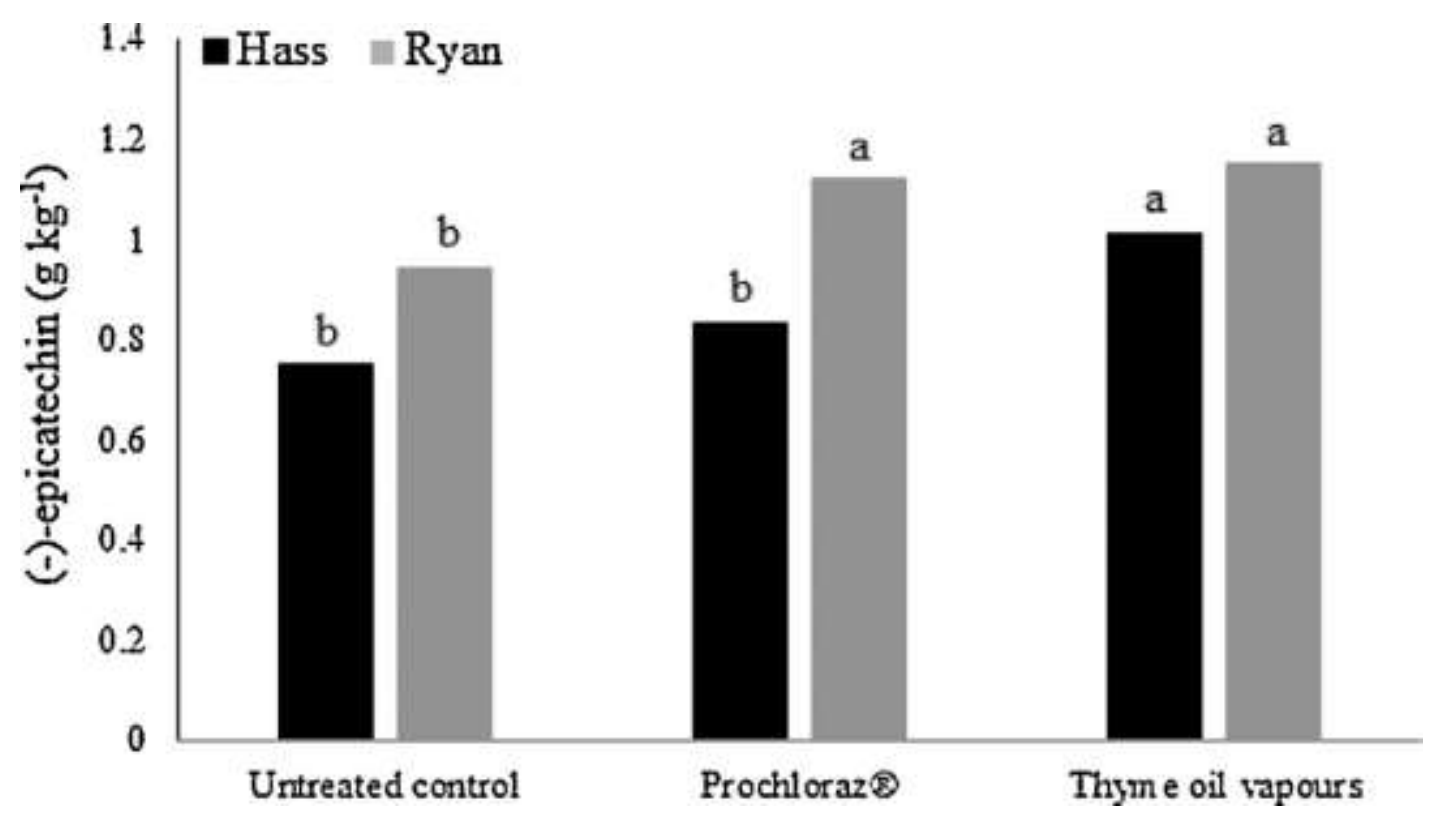

Fig. 4. Epicatechin content in naturally infected 'Hass' and 'Ryan' avocado fruit after $21 \mathrm{~d}$ of cold storage followed by $5 \mathrm{~d}$ shelf-life. Fruit were treated with thyme oil $\left(96 \mu \mathrm{L} \mathrm{L}^{-1}\right)$ vapours for $24 \mathrm{~h}$ at $20{ }^{\circ} \mathrm{C}$ or dipped for 5 min in $0.05 \%$ prochloraz ${ }^{\circledR}$-the commercial treatment. Different letters (for each cultivar) indicate significant difference between treatments $(\mathrm{P}<0.05)$ determined using the LSD test.

It is interesting to note that the exposure to thyme oil vapours induced higher expression of PAL genes that coincided with lower expression of LOX genes in both 'Hass' and 'Ryan' avocados. The PAL gene is a key factor in the phenylpropanoid pathway and is involved in the biosynthesis of phenolic compounds such as phenolic acids and flavonoids (Naoumkina et al., 2010; Singh et al., 2010). Their content has indeed been found to be higher in avocado fruit exposed to thyme oil vapours. On the other hand, the expression of the PAL gene was comparably higher in 'Ryan' than 'Hass' avocado fruit at similar time points. Phenolic compounds improve the antioxidant capacity and ROS scavenging activity, thus they can also contribute to enhanced resistance to pathogen challenge (Mittler, 2002). Increased antioxidant activity has previously been reported in 'Fuerte' and 'Hass' avocados inoculated with $C$. gloeosporioides spore suspension and then exposed to thyme oil vapours at $66.7 \mu \mathrm{L} \mathrm{L}^{-1}$ (Sellamuthu et al., 2013b). 
One of the key finding of this research is the fact that exposure of avocado fruit to thyme oil vapours prior to cold storage enhanced the accumulation of (-)-epicatechin. Epicatechin (flavonoid) is a product of the branching pathways downstream of the phenylpropanoid pathway (Alon et al., 2013). Therefore, the up-regulation of the PAL gene consequently resulted in the accumulation of this functional compound in fruit exposed to TO vapours as demonstrated. It has been previously suggested (Ardi et al., 1998) that the biosynthesis of epicatechin is involved in increasing the resistance of avocado fruit to C. gloeosporioides. Furthermore, the cultivars of avocado that are more resistant to fungal decay, were reported to have high (-)-epicatechin content, that declines with a slower rate during ripening (Prusky et al., 1988). Epicatechin is also involved in slowing the rate of decline of antifungal diene compound (AFD) via lowering/delaying the expression of the LOX genes (Prusky et al., 2013; Prusky et al., 1996), which in fact has been reported in this research. Therefore, it can be hypothesised that downregulation of LOX gene expression in 'Hass' and 'Ryan' avocado is the main mode of action of thyme oil vapours that contributed to enhanced resistance to anthracnose. The findings from this research suggest that in addition to the above mentioned mechanism of action, thyme oil vapours may prime the fruit (Conrath et al., 2002), and enable them to rapidly activate their defence mechanisms when challenged by pathogens. On the other hand, increase in epicatechin content via exposure to thyme oil vapour treatment is associated with many health benefits such as reducing the incidence cancer, cardiovascular diseases and type 2 diabetes (Park et al., 2014).

\subsection{Effect of thyme oil vapours on the physical properties of the fruit}

Fruit physical properties, i.e. firmness (Fig. 5) and skin colour (not shown) to ensure the stage of ripeness of the fruit did not differ significantly $(\mathrm{P}<0.05)$ between avocados exposed to thyme oil vapours and those treated with prochloraz ${ }^{\circledR}$. According to the International Organization for 
Standards (ISO 7619) fruit firmness of $1 \mathrm{~kg}$ represents ripe fruit. On the other hand, lower firmness values in untreated fruit were most likely associated with higher incidence of anthracnose disease, and progressing fruit decay as noted earlier in the current study. Similarly, results were noticed in our previous work (Bill et al., 2014b). Reddy et al. (2000) and Atkinson et al. (2012) reported that the application elicitor treatment such as chitosan in fruit also helps inhibit cell wall macerating enzymes such as pectate lyse (C. gloeosporiodes virulent factor) and cellulose thus retaining fruit firmness. Therefore, exposure of avocado fruit to thyme oil vapours prior to cold storage helped in maintaining fruit firmness by reducing the decay.

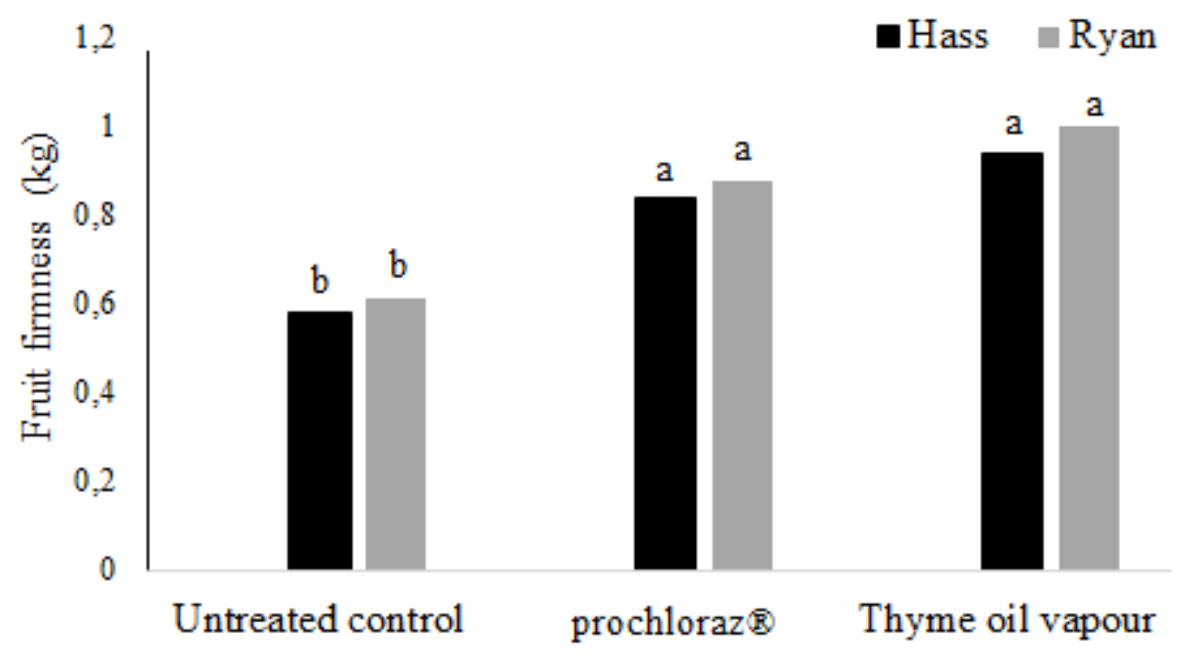

Fig. 5. Effect of thyme oil vapour exposure on fruit firmness (kg) in 'Hass' and 'Ryan' avocado after $21 \mathrm{~d}$ of cold storage followed by $5 \mathrm{~d}$ shelf-life. Fruit were treated with thyme oil $\left(96 \mu \mathrm{L} \mathrm{L}^{-1}\right)$ vapours for $24 \mathrm{~h}$ at $20{ }^{\circ} \mathrm{C}$ or dipped for $5 \mathrm{~min}$ in $0.05 \%$ prochloraz ${ }^{\circledR}$ - the commercial treatment. Different letters indicate significant difference $(P<0.05)$ determined using the LSD test.

\section{Conclusion}

Thyme oil vapours reduced the anthracnose disease incidence by acting as a natural elicitor of plant defence via up-regulation of PAL gene expression and enhanced biosynthesis of epicatechin. At the same time, thyme oil vapours led to down-regulation of LOX gene 
expression. All these components are involved in the response to fungal infection. Therefore, exposure to thyme oil vapours prior to cold storage is a promising alternative to commercial fungicide prochloraz ${ }^{\circledR}$ treatment that is currently being used by the industry.

\section{Acknowledgements}

This work was supported by the SA-France Bilateral research programme awarded to the Tshwane University of Technology (TUT), Pretoria West, South Africa. The authors also express their thanks to Dr. M. Chillet of CIRAD research station, Saint Pierre, Reunion Island for hosting the gene expression trials. Dr Marcin Glowacz is from Natural Resources Institute, University of Greenwich, United Kingdom; his visit was funded by the DST-NRF Fellowship for early career researchers from the UK jointly with the SARChi research chair grant for Phytochemical Food Network to Improve Nutritional Quality for Consumers, Grant number 98352.

\section{Conflict of Interest}

The authors declare that they have no conflict of interest.

\section{References}

Alon, M., Malka, O., Eaktaiman, G., Elbaz, M., Zvi, M.M.B., Vainstein, A., Morin, A., 2013. Activation of the phenylpropanoid pathway in Nicotiana tabacum improves the performance of the whitefly Bemisia tabaci via reduced jasmonate signalling. Plos One. 8 (10), e7619.

Ardi, R., Kobiler, I., Keen, N.T., Prusky, D., 1998. Involvement of epicatechin biosynthesis in the resistance of avocado fruits to postharvest decay. Physiol. Mol. Plant Pathol. 53, 269-285. 
Bill, M., Sivakumar, D., Beukes, M., Korsten, L., 2016. Expression of pathogenesis-related (PR) genes in avocados fumigated with thyme oil vapours and control of anthracnose. Food Chem. 194, 938-943.

Atkinson, R.G., Sutherland, P.W., Johnston, S.L., Gunaseelan, K., Hallett, I.C., Mitra, D., Brummell, D.A., Schroder, R., Johnston, J.W., Schaffer, R.J., 2012. Down-regulation of polygalacturonase alters firmness, tensile strength and water loss in apple (Malus x domestica) fruit. BMC Plant Biol. 12, 129.

Bill, M., Sivakumar, D., Korsten, L., Thompson, A.K. 2014a. Avocado fruit quality management during the postharvest supply chain. Food Rev. Int. 30, 169-202.

Bill, M., Sivakumar, D., Korsten, L., Thompson, A.K., 2014b. The efficacy of combined application of edible coatings and thyme oil in inducing resistance components in avocado (Persea americana Mill.) against anthracnose during post-harvest storage. Crop Prot. 64, 159167.

Bustin, S., Benes, V., Garson, J.A., Hellemans, J., Huggett, J., Kubista, M., Mueller, R., Nolan, T., Pfaffl, M.W., Shipley, G. L., Vandesompele, J., Wittwer, C.T., 2009. The MIQE guidelines: minimum information for publication of quantitative real time PCR experiments. Clin. Chem. 55, 611-622.

Calo, J.R., Crandall, P.G., O’Bryan, C.A., Ricke, S.C., 2015. Essential oils as antimicrobials in food systems - A review. Food Control, 54, 111-119.

Conrath, U., Pieterse, C.M.J., Mauch-Mani, B., 2002. Priming in plant-pathogen interactions. Trends Plant Sci. 7, 210-216.

Dreher, M., Davenport, A., 2013. Hass avocado composition and potential health effects. Crit. Rev. Food Sci. Nutr. 53, 738-750. 
EPA (Environmental Protection Agency), 2015. Active ingredients eligible for minimum risk pesticide products. https://www.epa.gov/minimum-risk-pesticides/active-ingredients-eligibleminimum-risk-pesticide-products (accessed on 20.07.2016).

Ferreyra, R., Selles, G., Saavedra, J., Ortiz, J., Zuniga, C., Troncoso, C., Rivera, S.A., GonzalezAguero, M., Defilippi, B.G., 2016. Identification of pre-harvest factors that affect fatty acid profiles of avocado fruit (Persea americana Mill) cv. 'Hass' at harvest. S. Afr. J. Bot. 104, 1520.

Glowacz, M., Rees, D., 2016. Using jasmonates and salicylates to reduce losses within the fruit supply chain. Eur. Food Res. Technol. 242, 143-156.

Karni, L., Prusky, D., Kobiler, I., Kobiler, D., 1989. Involvement of epicatechin in the regulation of the antifungal diene during the reactivation of quiescent Colletotrichum gloeosporioides infections of avocado fruits. Physiol. Mol. Plant Pathol. 35, 367-374.

Laird, K., Phillips, C., 2011. Vapour phase: a potential future use for essential oils as antimicrobials? Lett. Appl. Microbiol. 54, 169-174.

Landi, L., Romanazzi, G., 2011. Seasonal variation of defense-related gene expression in leaves from Bois noir affected and recovered grapevines. J. Agric. Food Chem. 59, 6628-6637.

Livak, K. J., Schmittgen, T. D., 2001. Analysis of relative gene expression data using real-time quantitative PCR and the 2- $\Delta \Delta \mathrm{C}(\mathrm{T})$ method. Method. 25, 402-408.

Lu, Q.Y., Zhang, Y., Wang, Y., Lee, R.P., Gao, K., Byrns, R., Heber, D. 2009. California Hass avocado. Profiling of carotenoids, tocopherols, fatty acids, and fat content during maturation and from different growing areas. J. Agric. Food Chem. 57, 10408-10413. 
Masek, T., Vopalensky, V., Suchomelova, P., Pospisek, M., 2005. Denaturing RNA electrophoresis in TAE agarose gels. Anal. Biochem. 336, 46-50.

Mauch, F., Mauch-Mani, B., Boller, T., 1988. Antifungal hydrolases in pea tissue. II. Inhibition of fungal growth by combinations of chitinase and $\beta$-1,3-glucanase. Plant Physiol. 88, 936-942.

Mittler, R., 2002. Oxidative stress, antioxidants and stress tolerance. Trends Plant Sci. 7, 405410.

Naoumkina, M.A., Zhao, Q., Gallego-Giraldo, L., Dai, X., Zhao, P.X., Dixon, R.A., 2010. Genome-wide analysis of phenylpropanoid defence pathways. Mol. Plant Pathol. 11, 829-846.

Park, J.H., Bae, J.H., Im, S.S., Song, D.K. 2014. Green tea and type 2 diabetes. Integrative Medicine Research. Integr Med Res. 3, 4-10.

Pedreschi, R., Hollak, S., Harkema, H., Otma, E., Robledo, P., Westra, E., Somhorst, D., Ferreyra, R., Defilippi, B.G., 2016. Impact of postharvest ripening strategies on 'Hass' avocado fatty acid profiles. S. Afr. J. Bot. 103, 32-35.

Prakash, B., Kedia, A., Mishra, P.K., Dubey, N.K., 2015. Plant essential oils as food preservatives to control moulds, mycotoxin contamination and oxidative deterioration of agrifood commodities - Potentials and challenges. Food Control 47, 381-391.

Prusky, D., 1996. Pathogen quiescence in postharvest diseases. Annu. Rev. Phytopathol. 34, 413-434.

Prusky, D., Alkan, N., Mengiste, T., Fluhr, R., 2013. Quiescent and necrotrophic lifestyle choices during postharvest disease development. Annu. Rev. Phytopathol. 51, 155-176. 
Prusky, D., Hamdan, H., Ardi, R, Keen N.T., 1996. Induction of biosynthesis of epicatechin in avocado suspension cells treated with an enriched $\mathrm{CO} 2$ atmosphere. Physiol. Mol. Plant Pathol. $48,171-178$.

Prusky, D., Keen, N.T., Eaks, I., 1983. Further evidence for the involvement of a preformed antifungal compound in the latency of Colletotrichum gloeosporioides on the unripe fruits. Physiol. Mol. Plant Pathol. 22, 189-198.

Prusky, D., Keen, N.T., Sims, J.J., Midland, S.L., 1982. Possible involvement of an antifungal diene in the latency of Colletotrichum gloeosporioides on unripe avocado fruits. Phytopathol. 72, $1578-1582$.

Prusky, D., Kobiler, I., Jacoby, B., 1988. Involvement of epicatechin in cultivar susceptibility of avocado fruits to Colletotrichum gloeosporioides after harvest. J. Phytopathol. 123, 140-146.

Prusky, D., Lichter, A., 2007. Activation of quiescent infections by postharvest pathogens during transition from the biotrophic to the necrotrophic stage. FEMS Microbiol. Lett. 268, 1-8.

Prusky, D., Plumbley, R.A., Kobiler., 1991. The relationship between antifungal diene levels and fungal inhibition during quiescent infection of unripe avocado fruits by Colletotrichum gloeosporioides. Plant Pathol. 40, 45-52.

Reddy, B.M.V., Angers, P., Castaigne, F., Arul, J., 2000. Chitosan effect on blackmold rot and pathogenic factors produced by Alternaria alternata in postharvest tomatoes. J. Am. Soc. Hortic. Sci. $125,742-747$.

Sellamuthu, P.S., Mafune, M., Sivakumar, D., Soundy, P., 2013a. Thyme oil vapour and modified atmosphere packaging reduce anthracnose incidence and maintain fruit quality in avocado. J. Sci. Food Agric. 93, 3024-3031. 
Sellamuthu, P.S., Sivakumar, D., Soundy, P., Korsten, L., 2013b. Enhancing the defence related and antioxidant enzymes activities in avocado cultivars with essential oil vapours. Postharvest Biol. Technol. 81, 66-72.

Singh, R., Rastogi, S., Dwivedi, U.N., 2010. Phenylpropanoid metabolism in ripening fruits Compr. Rev. Food Sci. Food Saf. 9, 398-416.

Sivakumar, D., Bautista-Banos, S., 2014. A review on the use of essential oils for postharvest decay control and maintenance of fruit quality during storage. Crop Prot. 64, 27-37.

USDA (U.S. Department of Agriculture), 2011. Avocado, almond, pistachio and walnut composition. Nutrient data laboratory. USDA national nutrient database for standard reference, Release 24.

Zhang, K., Zuo, Y., 2004. GC-MS determination of flavonoids and phenolic and benzoic acids in human plasma after consumption of cranberry juice. J. Agric. Food Chem. 28, 222-227. 